\title{
Characterisation of incinerator bottom ash from a Danish waste-to-energy plant: a step towards closing the material cycle
}

\author{
Rune J. Clausen ${ }^{* 1}$, Per Kalvig ${ }^{1}$ and Jonas Nedenskov ${ }^{2}$
}

RESEARCH ARTICLE | OPEN ACCESS

GEUS Bulletin Vol 43 | e2019430303 | Published online: 20 December 2019

https://doi.org/10.34194/GEUSB-201943-03-03

The UN Sustainable Development Goal 12, regarding responsible production and consumption of raw materials, guides ongoing international efforts to enhance sustainability in all parts of the mineral sector. Of particular interest, is improving the recyclability of secondary waste streams and thereby increasing the efficiency of recycling end-oflife products. Municipal solid waste - residual waste from household and industry - constitutes one of these secondary streams. It is typically incinerated in waste-to-energy plants producing two types of waste streams that carry a raw material resource potential: incinerator bottom ash (IBA) and incinerator fly ash (IFA). IBA is of particular interest in the recycling industry, where it is commonly recycled to produce three main fractions: (i) ferrous material, (ii) non-ferrous material, and (iii) residual slag. In most cases the two metal fractions are separated further downstream in the value chain, prior to smelting. The residual, non-magnetic fraction (typically $0-45 \mathrm{~mm}$ ) is used mainly as construction aggregate. Improvements in the efficiency of existing separation technologies are still being made, but less effort is focussed on characterising the fundamental composition and mineral resource potential of IBA. For this reason, the Urban-X project was launched by the Geological Survey of Denmark and Greenland (GEUS) to characterise the composition and resource potential of various waste streams at Amager Bakke waste-to-energy plant in Copenhagen, Denmark. This paper discusses some of the main outcomes of the Urban-X project with respect to IBA, and a full analysis of all waste streams analysed at Amager Bakke is available in Clausen et al. 2019.

\section{Incinerator bottom ash}

IBA material consists of all the non-combustible components of domestic and industrial waste. It can include components such as construction steel, household glass fragments, toys, electronic devices, cans, batteries, sofa springs, and boulder size aggregates. Some of the aggregates form during the in- cineration process and these are typically composed of silicarich melts with recognisable remnants of glassware, ceramics and metal fragments.

The extreme heterogeneity among IBA fragments is reflected not only in their chemical composition, but also in their variable density, shape and size from $2000 \mathrm{~mm}$ to less than $1 \mathrm{~mm}$ (Fig. 1).

IBA characteristics, including their physical form and chemical composition, are the result of a wide range of dynamic parameters. First, the composition of the input to the incinerators - the municipal solid waste - is physically and chemically heterogeneous and complex. Further, the temperature and fugacity conditions in the oven chamber vary locally due to the design of the chamber as well as irregular local flux-effects, generated by variations in the solid-waste input. All in all, IBA should be considered a multi-commodity deposit, for which detailed characterisation of the constituent materials is key to revealing its resource potential.

\section{Methods}

Four IBA samples were collected in duplicate from Amager Bakke plant each day for 30 consecutive days in November 2017 (series A-D, Fig. 2). Series D was preserved as an archive sample, and A, B and C were analysed for their composition. Each sample weighed $c .15 \mathrm{~kg}$, and the total sampled material weighed $c .1800 \mathrm{~kg}$.

\section{Representative sampling and physical characterisation}

Representative sampling of such heterogeneous material is a serious challenge. For example, the IBA is moving on a shaking belt and is not distributed evenly, IBA is hot (around $50-100^{\circ} \mathrm{C}$ ) and fragments can be very large. We attempted to overcome the challenges by sampling a cross-section with a steel shovel taking care to avoid subconsciously 'fishing' for 

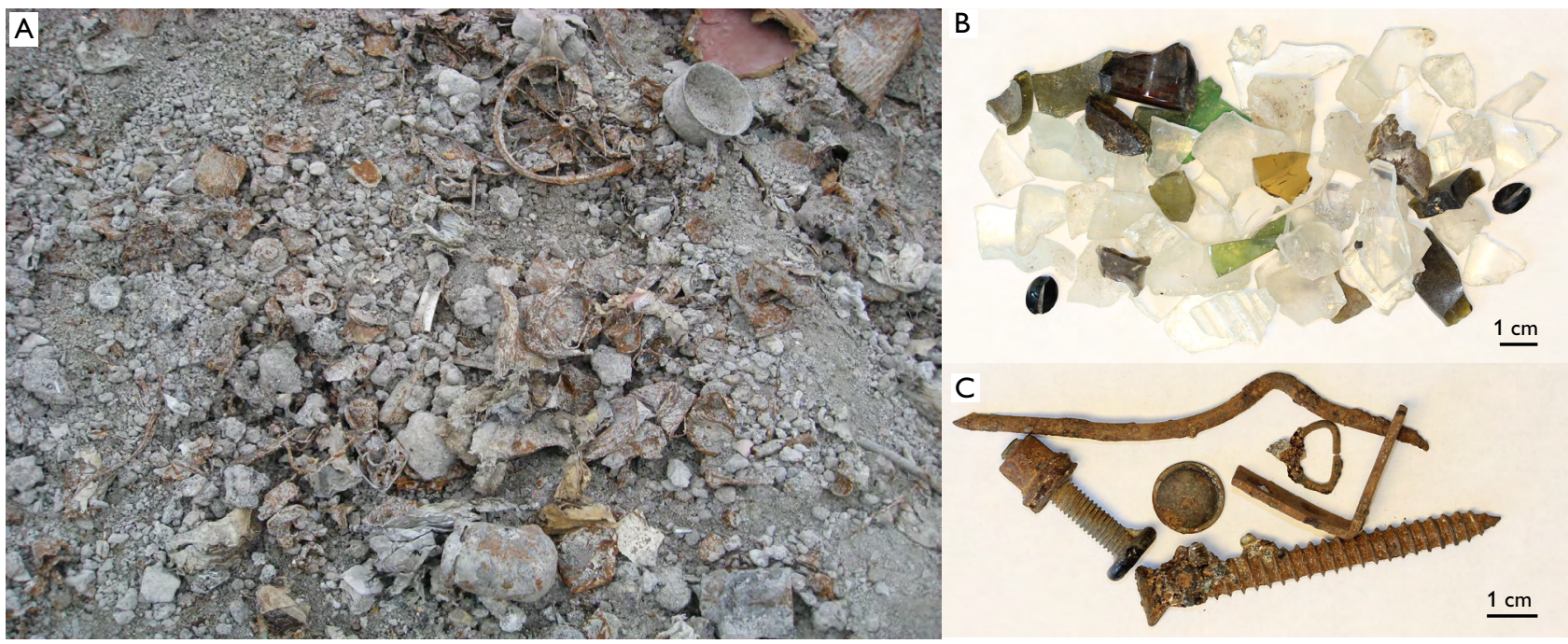

Fig. 1: Example waste from Amager Bakke waste-to-energy plant. A: Unprocessed incinerator bottom ash (reproduced from Clausen et al. 2019). B: Non-deformed glass fragments (sample number 567662 A; Clausen et al. 2019). C: Magnetic, non-deformed metal (sample number 567662 A; Clausen et al. 2019).

particular pieces. Fragments of up to $c .200 \mathrm{~mm}$ were sampled, though due to the sampling bias associated with large fragments (relative to the size of the sampler) among other things, only fragment sizes less than or equal to $63 \mathrm{~mm}$ were considered representatively sampled. To create four sample series (A-D) carrying the same 30-day representation, four samples was extracted immediately one after the other.

For physical characterisation, we combined one series into a composite sample, which represented the average IBA material collected during the 30 days of sampling (C series, Fig 2). First, all fragments larger than $63 \mathrm{~mm}$ were removed by hand and ruler in preparation for the splitter, where each sample was divided to retrieve a representative subsample. Combining all 30 subsamples of series $C$ produced a composite sample of $17 \mathrm{~kg}$.

The composite sample was then sieved into seven size fractions, which were further separated to isolate a number of characteristic components: ferro magnetic metal, nonmagnetic metal, glass, ceramics and building aggregates and melt. Glass, ceramics and building aggregates were identified by manual-visual sorting. Ferro magnetic metal was captured by a magnet and non-magnetic metal was identified with a metal-detector. The remaining material was classed as predominantly melt - fragments or conglomerations of fragments, which were partly or entirely melted, and did not belong to the other categories. The resulting fractions and material classes were weighed.

All metal fragments underwent further analysis with $\mathrm{X}$-ray fluorescence (XRF) to categorise them according to alloying elements; non-magnetics were subdivided into alu- minium, alloyed aluminium, copper alloyed copper, and other metals. Additional subdivisions were made according to the degree of degradation; glass for example was subdivided into four sub-classes. This part of the study is not reported in this article but can be found in Clausen et al. 2019.

\section{Chemical characterisation}

A classical mineral exploration approach would be to produce an IBA 'whole-rock' chemical signature to identify potentially economic elements and minerals. But this is neither possible nor meaningful for IBA material for the following reasons:

1. The technical challenge: Homogenisation by means of crushing and milling of IBA material is expensive, if not impossible, due to the content of ductile metal fragments.

2. The distributional challenge: The 'whole rock' chemical signature represents elements hosted by myriad chemically different fragments of materials and melts. However, it does not reveal the extent to which the element is available to mining/recycling, since it does not describe the size, shape and elemental composition of the particular fragments it is associated with.

It follows that neither the 'ore grade' nor the 'ore value' of IBA can be established only on the basis of bulk geochemical data. However, chemical data may point to elements occurring in elevated concentrations, on which further studies are required in order to assess their economic potential. This approach was applied in the Urban-X project where a total of 62 


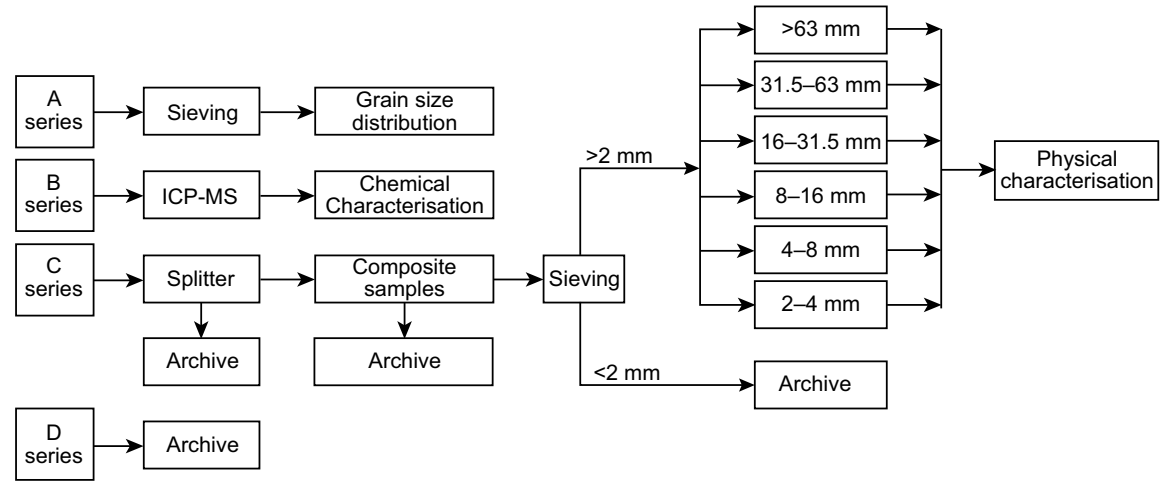

Fig. 2. Sampling workflow and methods applied to each series (A-D) of sampled IBA (modified from Clausen et al. 2019).

chemical elements were analysed by ICP-MS and ICP-OES on each of the 30 IBA samples (the $0-63 \mathrm{~mm}$ size fraction from the $B$ series after removing magnetic metal; Fig 2). Samples were prepared and analysed by Actlabs, Canada. A full description of sample preparation and analytical methods is supplied as supplementary information (File S1; https://doi. org/10.34194/GEUSB-201943-03-03).

\section{Results and discussion}

Five material classes dominated the coarse fraction of the IBA-bulk sample: magnetic metal (29 wt\%), non-magnetic metal ( $6 \mathrm{wt} \%)$, glass $(14 \mathrm{wt} \%)$, ceramics and building aggregates $(14 \mathrm{wt} \%)$ and melt ( $37 \mathrm{wt} \%$; Figs 1B, C). The composite IBA-bulk sample consisted of $66 \mathrm{wt} \%$ coarse $(2-63 \mathrm{~mm}) \mathrm{ma}-$ terial and $34 \mathrm{wt} \%$ fine $(<2 \mathrm{~mm})$ material.

Comparing the physical characterisation of each sieved fraction, it follows that each material class correlates to some extent with fragment size (Fig 3). For example, building aggregates and magnetic metals are concentrated in the $>32 \mathrm{~mm}$ fractions, while glass and non-magnetic metal are concentrated in the $<32 \mathrm{~mm}$ fractions. Distribution of the non-magnetic fraction is however less distinct across the various material classes (Fig. 3).

The annual resource potential of the five main classes in the 2-200 $\mathrm{mm}$ material fraction from the Amager Bakke plant are estimated and presented in Table 1 . The total mega tons per annum (Mtpa) IBA production in Denmark and the EU-28 is $0.6 \mathrm{Mtpa}$ (Miljøstyrelsen 2016) and $16 \mathrm{Mtpa}$ (ISWA 2015), respectively. Assuming the distribution of the five material groups measured for Amager Bakke IBA is representative of IBA in Denmark and the EU, we can apply these class distributions to the national and EU-level data (Table 1). For example, magnetic- and non-ferrous scrap could be as high as 230000 tpa and 50000 tpa, respectively, in Denmark, and 4200000 tpa and 1000000 tpa, respectively, in the EU-28 (Table 1). This EU-28 estimate must,

Table 1. Estimated annual resource volume produced by Amager Bakke waste-to-energy (WtE) plant. Potential volume in Denmark and the EU-28 is extrapolated from the distribution among raw material groups observed at Amager Bakke

\begin{tabular}{|c|c|c|c|c|c|c|}
\hline & & \multicolumn{3}{|c|}{ Amager Bakke } & \multirow{2}{*}{$\begin{array}{l}\text { All WtE incinerators } \\
\text { Denmark } \\
\text { Estimated volume } \\
\text { (tpa) }\end{array}$} & \multirow{2}{*}{$\begin{array}{l}\text { All WtE incinerators } \\
\text { EU-28 } \\
\text { Estimated volume } \\
\text { (tpa) }\end{array}$} \\
\hline & & $\begin{array}{l}\text { Measured } \\
\text { (wt\%) }\end{array}$ & $\begin{array}{l}\text { Adjusted } \\
(w t \%)^{\mathrm{a}}\end{array}$ & $\begin{array}{l}\text { Estimated volume } \\
\qquad \text { (tpa) }\end{array}$ & & \\
\hline \multicolumn{2}{|c|}{$>63$ mm (mostly magnetic metal) } & & $5^{b}$ & 4000 & 30000 & 80000 \\
\hline \multirow{5}{*}{$2-63 \mathrm{~mm}$} & Ceramics and aggregates & 14 & 11 & 9100 & 68000 & 1800000 \\
\hline & Glass & 14 & 10 & 8400 & 63000 & 1700000 \\
\hline & Non-ferrous metal & 6 & 6 & 4600 & 34000 & 910000 \\
\hline & Magnetic metal (steel) & 29 & 23 & 18000 & 137000 & 3600000 \\
\hline & Slag melt & 37 & 29 & 24000 & 177000 & 4700000 \\
\hline \multicolumn{2}{|c|}{$0-2 \mathrm{~mm}$ fraction } & & $15^{c}$ & 12000 & 91000 & 2400000 \\
\hline \multicolumn{2}{|l|}{ Total } & 100 & 100 & 80000 & $600000^{d}$ & $16000000^{\mathrm{e}}$ \\
\hline
\end{tabular}

a Measured content adjusted to include estimates of the $>63 \mathrm{~mm}$ and $0-2 \mathrm{~mm}$ fractions.

${ }^{b}$ Rough estimate of the $>63 \mathrm{~mm}$ fragments in IBA from Amager Bakke.

c Production from Amager Bakke, as estimated by Amager Resource Center.

d IBA production in Denmark based on multiple sources (Miljøstyrelsen 2016; Dansk Affaldsforening et al. 2016).

e IBA production in the EU-28 estimated by ISWA (2015). 
Table 2. Content of selected elements in incinerator bottom ash produced by the Amager Bakke waste-to-energy plant



${ }^{a}$ Obtained from periodictable.com.

${ }^{b}$ Earth crust enrichment factor is the element concentration relative to crustal concentration.

c Measured concentration of 10 fragments of melt materials from Amager Forbrænding, 2015 (Kalvig et al. 2016).

however, be considered speculative and further studies are needed to quantify the resource potential in the EU.

Complete chemical analysis of the $0-63 \mathrm{~mm}$ IBA fraction can be found in Clausen et al. (2019). Here we present only the nine elements that occurred in concentrations 10 times higher than the average crustal concentration and are thus considered candidates for resource extraction (Table 2). When ranking these elements according to their level of enrichment compared to crustal concentration, $\mathrm{Sb}, \mathrm{Au}$ and $\mathrm{Pb}$ rank highest.

Since the various classes of potentially economic materials are unevenly distributed throughout the IBA size fractions, it follows that the chemical composition also varies with grain size. Therefore, a relevant question is, where in the IBA are the nine elements in Table 2 concentrated, i.e. elevated above the average (0-63 $\mathrm{mm}$ fraction) concentration?

The $2-63 \mathrm{~mm}$ fraction of melt fragments were not measured in this study, but similar IBA material $(20-40 \mathrm{~mm}$ size fraction of melt fragments) was analysed at Amager Forbrænding in 2015 (Kalvig et al. 2016; in service between 1970 and c. 2017, after which the new Amager Bakke plant operates in its place). The $20-40 \mathrm{~mm}$ melt fraction at Amager Forbrænding has a similar composition to the $0-63 \mathrm{~mm}$ fraction at Amager Bakke (Table 2).

In general, the 2-63 mm non-melt fragments (i.e. glass, building materials, magnetic metals and non-magnetic

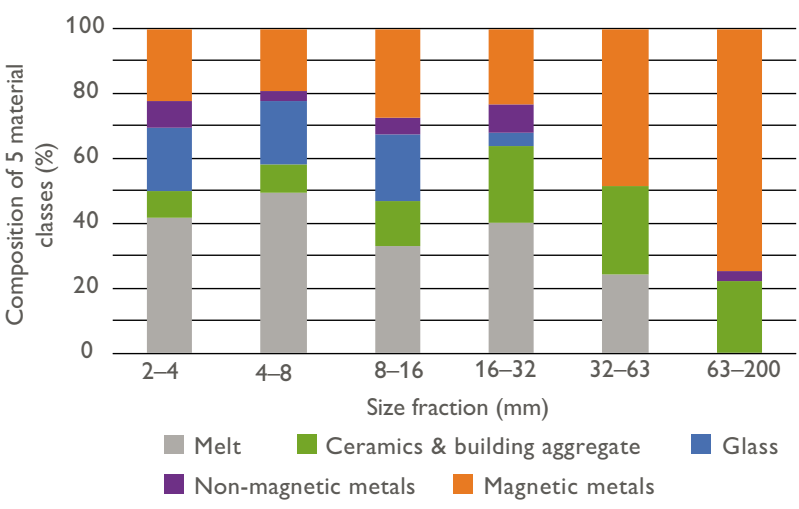

Fig. 3. The distribution of main components according to fragment size. The characterized 2-63 $\mathrm{mm}$ fractions were considered representative of the total IBA material. The $63-200 \mathrm{~mm}$ was not considered representative due to its size relative to the sampler, but a rough characterisation using a magnet was made nonetheless on the sampled material (modified from Clausen et al. 2019).

metal) originates from products used in household and industry, in which the elements in Table 2 would not serve a functional purpose and are undesirable for economic, health and environmental reasons. Measurements with XRF were carried out to see if any of the elements in Table 2 could be detected among each category of non-melt fragments. None of the elements, except for zinc, registered above the limit of detection. Zinc only registered in measurable quantities in a few non-ferrous metal fragments (data not shown). The XRF measurements thus support our general assumption, that the nine elements are mostly absent in the $2-63 \mathrm{~mm}$ non-melt fragments.

We can thus assume that the $0-2 \mathrm{~mm}$ fraction is a source of elevated concentrations of the nine elements of interest. Previous studies in Holland support the notion that heavy metals are concentrated in the IBA fines (Muchova et al. 2009; Muchová \& Rem 2006).

\section{Summary and outlook}

IBA flows at the Amager Bakke plant likely carry a secondary raw material potential that is not yet fully realised. These include: (1) glass, (2) increased recycling efficiency on ferrous and non-ferrous metals, (3) higher value usage of melts and ceramics e.g. in concrete and asphalt and (4) potential extrac- 
tion of metals such as antimony, gold, lead and zinc from the $0-2 \mathrm{~mm}$ fraction.

Future work should characterise these resource potentials in greater detail to enable their commercial exploitation. In addition, a comprehensive physical and chemical characterisation of the IBA at similar plants would be a powerful tool to characterise the drivers of IBA resource potential and to provide a foundation for closing some of the major gaps in the circular economy.

To further enable commercial exploitation, efforts should be made to develop a preparatory recycling method of IBA flows. A preparatory method could for example involve a washing phase, as part of the existing water-cooling basin at Amager Bakke - a method whereby clean fragments larger than $2 \mathrm{~mm}$ are removed in one material stream, and fines undergo a density separation to separate a heavy density concentrate. This method could (1) enable recycling of clean, non-metal fragments due to the absence of heavy metals - and make the fragments available for visual sorting techniques, (2) increase performance of existing mechanical sorting techniques applied to metal fragments, (3) enable recovery of antimony, gold, lead and zinc from the heavy concentrate, (4) save storage space currently used to store IBA for carbonation (whereby heavy elements are stabilised) - which in turn would minimise the oxidation of stored metals.

\section{References}

Clausen R., Kalvig, P. \& Nedenskov, J. 2019: Karakterisering af slagge og flyveaske fra affaldsforbrændingsanlægget Amager Bakke. Overvejelser om råstofpotentialet. 2. udgave. MiMa rapport 2019/1, $231 \mathrm{pp}$. Videncenter for Mineralske Råstoffer og Materialer (MiMa) and Geological Survey of Denmark and Greenland (GEUS), Denmark. Accessed November 2019 at http://mima.geus.dk/wp-content/uploads/Karakerisering-af-slagge-og-flyveaske-fra-A mager-Bakke-Overvejelser-omr\%C3\%A5stofpotentialet-2.-Udgave-Clausen-et-al-2019.pdf
Dansk Affaldsforening et al. 2016: BEATE, Benchmarking af affaldssektoren 2016 (data fra 2015), Forbrænding, 29 pp. The Danish Energy Agency, Denmark. Accessed November 2019 at https://ens.dk/sites/ens.dk/files/ Affald/beate_afrapportering_forbraending_2016_29maj2017.pdf

ISWA 2015: Bottom ash from WtE plants - Metal recovery and utilization. Unpublished report, International Solid Waste Association (ISWA), Austria.

Kalvig, P., Clausen, R. \& Nedenskov, J. 2016: Karakterisering af slagge og røggasaffald fra Amager Ressource Center, 161 pp. Unpublished report. Videncenter for Mineralske Råstoffer og Materialer, Denmark.

Miljøstyrelsen 2018: Affaldsstatistik 2016, 66 pp. The Danish Environmental Protection Agency, Denmark. Miljøprojekt no. 2020. https:// www2.mst.dk/Udgiv/publikationer/2018/06/978-87-93710-39-9.pdf

Miljøstyrelsen 2016: Kommissionens forslag til ændring af bilag III i affaldsdirektivet (2008/98EF) med hensyn til fareegenskaber HP 14 (økotoksisk) (komitesag). Notat til Folketingets Europaudvalg. Ref. THFRU. https://www.ft.dk/samling/20161/almdel/mof/bilag/35/1678142/index.htm

Muchová, L. \& Rem, P. C. 2006: Metal content and recovery of MSWI ash in Amsterdam. In: V. Popov, V. et al. Waste Management and the Environment III. WIT Transactions on Ecology and the Environment, 92. 211-216. https://doi.org/10.2495/WM060231

Muchova, L., Bakker, E. \& Rem, P. 2009: Precious Metals in Municipal Solid Waste Incineration Bottom Ash. Water Air Soil Pollution: Focus 9, 107-116. https://doi.org/10.1007/s11267-008-9191-9

\section{Acknowledgements}

Our thanks go to the reviewers Tod Waight and Gang Liu for their comments, and to Marija Blazanovic, Tonny B. Thomsen, Nynke Keulen, Sebastian Næsby Malkki and Frederik Tevil for their help and guidance. The urban-X project was funded by Amager Bakke and Videncenter for Mineralske Råstoffer og Materialer (MiMa).

\section{How to cite}

Clausen, R.J., Kalvig, P. \& Nedenskov, J. 2019: Characterisation of incinerator bottom ash from a Danish waste-to-energy plant: a step towards closing the material cycle. Geological Survey of Denmark and Greenland Bulletin 43, e2019430303. https://doi.org/10.34194/ GEUSB-201943-03-03

\footnotetext{
*Corresponding author: Rune Clausen |E-mail: rjc@geus.dk

${ }^{1}$ Geological Survey of Denmark and Greenland (GEUS), Øster Voldgade 10, DK-1350, Copenhagen K, Denmark.

${ }^{2}$ Amager Ressource Center, Vindmollevej 6, DK-2300, Copenhagen S, Denmark.
} 